\title{
Heterotopic salivary gland tissue at the base of the neck: A case report
}

\author{
John Muen Hwang BSc, Donald Ian Robertson MD, Enzio Magi MD \\ Department of Surgery, Division of Plastic Surgery, University of Calgary, Foothills Hospital, Calgary, \\ Alberta
}

\begin{abstract}
JM Hwang, DI Robertson, E Magi. Heterotopic salivary gland tissue at the base of the neck: A case report. Can J Plast Surg 2000;8(1):33-35.

A case report of ectopic salivary gland tissue at the base of the neck is presented. Heterotopic salivary gland tissue (HSGT) is found infrequently in the neck. This lesion, present since birth, typically presents as a discharging sinus in the base of the neck. Benign and malignant neoplasms may arise in such HSGT. The origin of HSGT is thought to be heteroplasia of the epithelium of the precervical sinus of His.
\end{abstract}

Key Words: Ectopic salivary gland tissue; Heterotopic salivary gland tissue; Neck

Tissu hétérotope de glandes salivaires localisé à la base du cou : un rapport de cas

RÉSUMÉ : Un rapport de cas sur du tissu ectopique des glandes salivaires localisé à la base du cou est présenté. On trouve parfois du tissu hétérotope de glandes salivaires dans le cou. Cette lésion, présente à la naissance, se caractérise par un écoulement à la base du cou. Des néoplasies bénignes ou malignes peuvent se développer dans ce tissu hétérotope de glandes salivaires. On pense que cette affection a pour origine une hétéroplasie de l'épithélium du sinus précervical de His.

$\mathrm{S}^{\mathrm{a}}$ livary gland tissue is usually found in the three major salivary glands and in minor salivary glands scattered within the oral cavity, pharynx and upper airway. The presence of heterotopic salivary tissue has been reported in tissues as diverse as colon, tonsils, pituitary gland, middle ear and lymph node (1-4). Cervical heterotopias are an uncommon lesion, but the majority have presented as painless, discharging masses and have been found in the lower third of the neck near the anterior border of the sternocleidomastoid (5).

\section{CASE PRESENTATION}

A 41-year-old white female presented with a punctate opening over the medial third of her right clavicle that was likely present since birth (Figure 1). The patient's only complaint

Correspondence and reprints:Dr Enzio Magi, Department of Surgery, Division of Plastic Surgery, University of Calgary, Foothills Hospital, 1403 - 29th Street NW, Calgary, Alberta T2N 2T9. Telephone 403-571-3130 or 403-670-1905, fax 403-571-3133, e-mail magis@cadvision.com was of a clear, odourless discharge from the punctum during meals, which necessitated the use of tissues or a napkin to absorb the drainage. A probe could be introduced to a depth of approximately $1 \mathrm{~cm}$ and a subtle fullness was palpable about the sinus. At the patient's request, the sinus and surrounding tissue were excised. Histopathological examination revealed mixed but mainly serous salivary gland tissue embedded in muscle and connective tissue (Figures 2,3).

\section{DISCUSSION}

Heterotopic salivary tissue at the base of the neck has been reported as early as 1789. In the English literature, there have been scattered studies, the largest being those of Youngs and Scofield (6), Singer et al (7) and Lassaletta-Atienza et al (8). The most common features have been a sinus opening on the anterior aspect of the lower neck, with or without clear, odourless drainage related to meals. Most of the lesions were detected during infancy or childhood (9-13). 


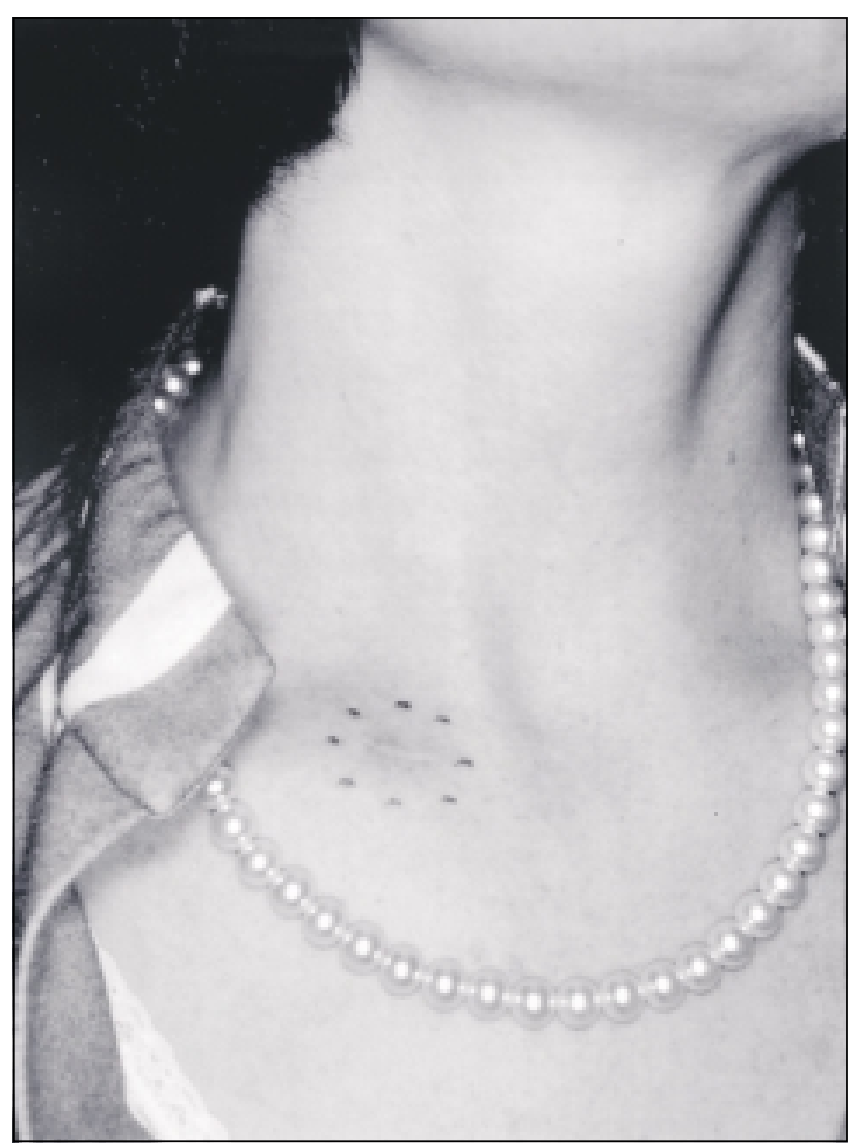

Figure 1) Heterotopic salivary gland tissue removed from the site surrounded by black markings

Like salivary gland tissue within the normal salivary glands, heterotopias are capable of neoplastic transformation (both benign and malignant) but do not seem to be at any increased risk for developing into adenocarcinomas $(14,15)$. Unfortunately, there is no method of distinguishing tumours of heterotopic cervical tissue from metastases from the major and minor salivary glands. Thus, clinical examination of the head and neck has been proposed as the appropriate method for following patients with heterotopic salivary gland neoplasms (16).

The exact origins of heterotopic salivary gland tissue (HSGT) are a topic of speculation. The most accepted hypothesis was proposed by Youngs and Scofield (6). They suggested that HSGT arose from the heteroplastic ectodermal lining within the remnants of the precervical sinus of His. The sinus of His is formed in the second month of embryonic life by the overlapping of the second, third and fourth bronchial clefts. Normally, the sinus involutes by the end of the second month of gestation. Youngs and Scofield (6) postulated that defective closure of this sinus and retention of heteroplastic ectoderm within its remnant best explain ectopic salivary gland tissue at the base of the neck.

Other theories include the persistence of a 10th nerve placodal duct, downward migration of salivary gland tissue within inclusions in lymph nodes, and anomalous differentia-

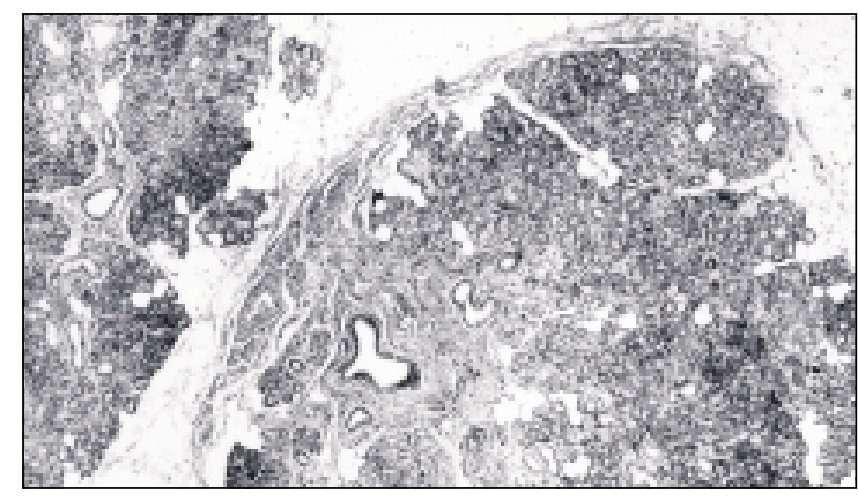

Figure 2) Lobules of mixed (mainly serous) salivary gland tissue

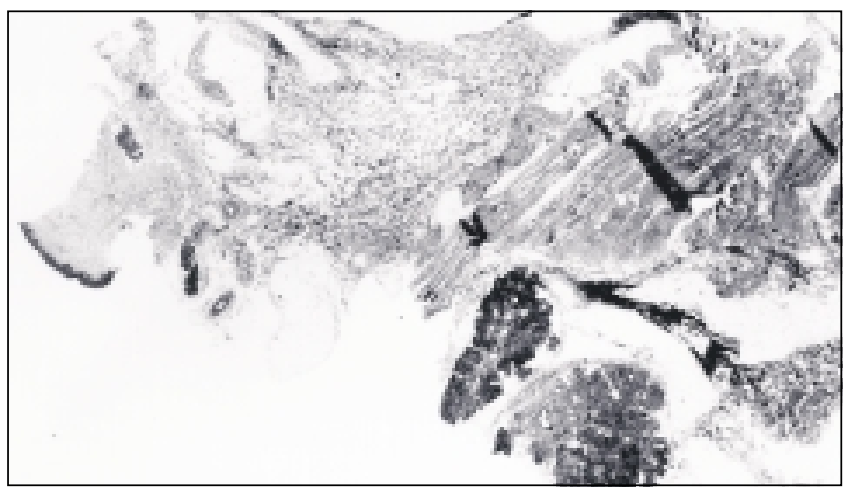

Figure 3) Mixed salivary gland tissue in subcutaneous fat with underlying muscle

tion and heteroplasia of epithelium (7). Jernstrom and Prietto (17) proposed that aberrant glandular tissue of pharyngeal pouch origin may migrate downward with the thyroid gland and differentiate into salivary gland tissue at the heterotopic site.

Treatment is surgical excision and is often done to rule out more common causes of neck lumps and sinuses. Histological examination has typically revealed lobules of mixed (mucinous and serous) salivary gland tissue that is indistinguishable from normal salivary gland tissue.

\section{REFERENCES}

1. Weitzner S. Ectopic salivary gland tissue in submucosa of rectum. Dis Colon Rectum 1983;26:814-7.

2. Banedee AR, Soaines JV, Birchall JP, Reiad C, Bray RJ. Ectopic salivary gland tissue in the palatine and lingual tonsil. Int J Paediatr Otorhinolaryngol 1993;27:159-62.

3. Hinni ML, Beatty CW. Salivary gland choristoma of the middle ear: report of a case and review of the literature. Ear Nose Throat $\mathrm{J}$ 1996;75:422-4.

4. Batsakis JG. Heterotopic and accessory salivary tissues. Ann Otol Rhinol Laryngol 1986;95:434-5.

5. Gudbrandsson FK, Liston SL, Maisel RA. Heterotopic salivary tissue in the neck. Otolaryngol Head Neck Surg 1982;90:279-82.

6. Youngs LA, Scofield HH. Heterotopic salivary gland tissue in the lower neck. Arch Pathol 1967;83:550-6.

7. Singer MI, Applebaum EL, Loy KD. Heterotopic salivary tissue in the neck. Laryngoscope 1979;89:1772-8.

8. Lassaletta-Atienza L, Lopez-Rios F, Martin G, et al. Salivary gland heterotopia in the lower neck: a report of five cases. Int J Pediatr Otorhinolaryngol 1998;43:153-61. 
9. Stingle WH, Priebe CJ Jr. Ectopic salivary gland and sinus in the lower neck. Ann Rhinol Laryngol 1974;83:379-81.

10. Ostfield E, Fisher J. Ectopic salivary gland in the lower neck. Isr J Med Sci 1979; 12:463-4

11. Romanao J, Marino CT. Heterotopic salivary tissue at the base of the neck. Int J Dermatol 1982;21:42-3.

12. Mair WS, Bjorang G, Keamey MS. Heterotopic cervical salivary glands. J Otolaryngol 1977;12:35-40.

13. Hulbert JC. Ectopic mixed salivary tumor in the neck. J Laryngol Otol 1978;92:533-6.
14. Zajtchuk J, Patow CA, Hywns VJ. Cervical heterotopic salivary gland neoplasms: a diagnostic dilemma. Otolaryngol Head Neck Surg 1982;90:178-81.

15. Pesavento G, Ferlito A. Benign mixed tumor of heterotopic salivary gland tissue in upper neck. Report of a case with a review of the literature on heterotopic salivary gland tissue. Laryngol Otol 1976;90:577-84.

16. Ross DE Sukis AE. Salivary gland tumors in ectopic sites. Laryngoscope 1971;81:558-64.

17. Jernstrom P, Prietto CA. Accessory parotid gland tissue at base of neck. Arch Pathol 1962;73:53-60. 